\title{
MtDNA variation in Apis cerana populations from the Philippines
}

\author{
P. DE LA RÚA*†, U. E. SIMON†, A. C. TILDE§, R. F. A. MORITZ† \& S. FUCHS \\ $\dagger$ Institut Zoologie-Molekulare Ökologie, Martin Luther Universität Halle/Wittenberg, Kröllwitzerstr. 44, D-06099 \\ Halle/Saale, Germany, łInstitut für Immunologie, Ludwig Maximilians Universität, Goethestr. 31, 80336 München, \\ Germany, §Institute of Biological Sciences, University of the Philippines Los Baños College, Laguna, 4031 \\ Philippines and Institut für Bienenkunde, Johann Wolfang Goethe Universität Frankfurt, Karl von Firsch Weg 2, \\ D-61440 Oberursel, Germany
}

\begin{abstract}
The cavity-nesting honeybee Apis cerana occurs in Asia, from Afghanistan to China and from Japan to southern Indonesia. Based on morphometric values, this species can be grouped into four subspecies: A. c. cerana, A. c. indica, A. c. japonica and A. c. himalaya. In order to analyse the geographical variability of $A$. $c$. indica from the Philippine Islands, 47 colonies from different locations in three of the larger islands (Mindanao, Luzon and Palawan) and four of the Visayan Islands (Panay, Negros, Cebu and Leyte) were studied. Genetic variation was estimated by restriction and sequence analysis of PCR-amplified fragments of the tRNAleu-COII region. We found four different haplotypes, $\mathrm{Ce} 1, \mathrm{Ce} 2, \mathrm{Ce} 3$ and $\mathrm{Ce} 4$, that discriminate among the bee populations from different islands. The $\mathrm{Ce} 1$ haplotype is present in Mindanao and Visayan Islands, $\mathrm{Ce} 2$ is restricted to Luzon, and both $\mathrm{Ce} 3$ and $\mathrm{Ce} 4$ are only present in Palawan. Phylogenetic analysis of the sequences shows a great intraspecific variability, is in accordance with the geological history of these islands and partially agrees with some previous morphological and molecular studies.
\end{abstract}

Keywords: Apis, biogeography, mtDNA, Philippines.

\section{Introduction}

The eastern cavity-nesting honeybee, Apis cerana $\mathrm{F}$., is widespread over Asia and occupies a distribution extending from Afghanistan to China and from Japan to southern Indonesia (Ruttner, 1988). This species has been grouped based on morphometric analyses (Ruttner, 1988) in four subspecies with different distribution ranges: A. cerana cerana from Afghanistan, Pakistan, north India, China and north Vietnam, $A$. $c$. indica from south India, Sri Lanka, Bangladesh, Burma, Malaysia, Indonesia and the Philippines, A. c. japonica from Japan and $A$. c. himalaya from central and east Himalayan Mountains (Smith, 1991). These subspecies include many populations some of which are geographically isolated, such as those in the Philippines archipelago. As on other oceanic islands, these populations may have undergone evolutionary changes giving rise to reproductively isolated populations.

Mitochondrial DNA has proved to be an important tool in phylogenetic studies of insects (DeSalle, 1992; Simon et al., 1994) and especially of honeybees (Cornuet

*Correspondence. E-mail: pdelarua@fcu.um.es
\& Garnery, 1991; Smith, 1991; Garnery et al., 1992; Moritz et al., 1994) in particular, because the complete sequence of the mtDNA of $A$. mellifera is available (Crozier \& Crozier, 1993).

The mtDNA of Apis species has an intergenic region, between the tRNAleu gene and the second subunit of the cytochrome oxidase gene (COII), that shows length polymorphism (Cornuet et al., 1991). The nucleotide sequence of this region shows a combination of units that defines three major evolutionary lineages of A. mellifera mtDNA. A simple test using PCR amplification of this intergenic region and subsequent restriction with the enzyme DraI has been developed (Garnery et al., 1993) and used to discriminate among the mitochondrial haplotypes of A. mellifera subspecies and races (Moritz et al., 1994, 1998; Garnery et al., 1995; De la Rúa et al., 1998). Apis cerana is closely related to A. mellifera (Garnery et al., 1991; Willis et al., 1992), and shares the presence of this intergenic region. In A. cerana the region is of $89 \mathrm{bp}$ and has a high A-T content, which makes it suitable for the aforementioned test (Cornuet et al., 1991).

Smith \& Hagen (1997) used the noncoding intergenic region of $A$. cerana to study the intraspecific 
biogeography of different populations sampled over the distribution range of this species. They found two types of mtDNA with western and eastern distributions, respectively, and a third, short, type with most of the intergenic region absent, which was present in two geographically distant islands (Taiwan and Sulawesi). In their phylogenetic analysis of this region they found two well supported groups: the Sundaland group (populations from Malaysia, Borneo, Java, Bali, Lombok, Timor and Flores) and the Philippine group (populations from Luzon, Mindanao and Sangihe). A third group with the eastern bees from the mainland from India to Japan was less well supported.

The Philippines is a group of islands containing $A$. cerana indica populations that have been isolated since the Pleistocene, except for those on Palawan (Smith, 1991). Morphological studies have shown the presence of three different groups, restricted to different islands: (i) the Philippine general group that includes bees from the lowlands of Luzon, the Visayas Islands and Mindanao; this group shows marked north-south contrasts, attributable either to further Luzon-lowland and Mindanao-Visayas subgrouping or to a clinal transition over this extended geographical range; (ii) the Luzon highland group, consisting of bees from the highlands of Mountain Province; and (iii) the Palawan group (Tilde et al. unpubl. obs.).

The aim of this work was to investigate the genetic variability at the mitochondrial level of $A$. cerana indica from the Philippine Islands using $\operatorname{DraI}$ analysis and the partial sequence of the tRNAleu-COII region. Specifically, the genetic differentiation and the phylogenetic relationships among these populations were studied. The results support an alternative grouping of these bees, slightly different from the previous morphology-based one. Evolutionary mechanisms specific to isolated island populations may explain these results.

\section{Materials and methods}

\section{Sampling}

Forty-seven colonies were sampled from different islands and localities in the Philippine archipelago as shown in Fig. 1 and Table 1. The colonies from Luzon were sampled in two different geographical locations, eight from the highlands and eight from the lowlands. The Visayan Islands are a group of islands located in the centre of the archipelago. Four islands were sampled in this study: Panay, Cebu, Leyte and Negros. Each sample consisted of three to five worker bees per colony preserved in absolute ethanol. The samples were stored at $4^{\circ} \mathrm{C}$ until DNA extraction.

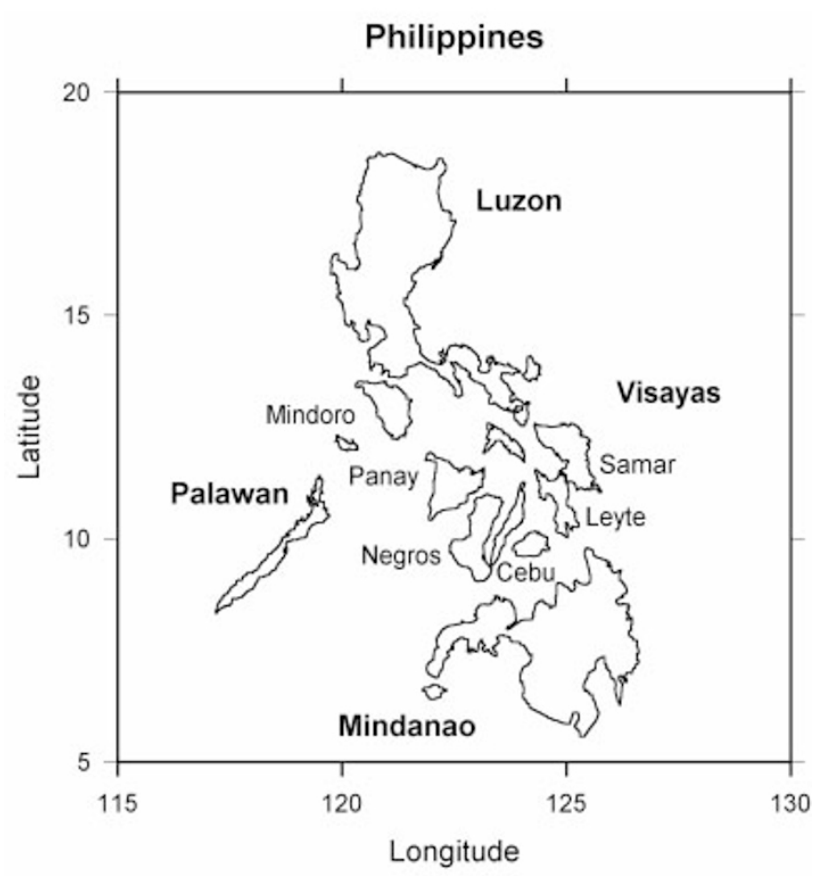

Fig. 1 Map of the Philippine Islands showing the islands sampled.

\section{DNA extraction}

Workers were rinsed for $1 \mathrm{~h}$ in honeybee ringer at room temperature and vacuum-dried overnight following Garnery et al. (1993). Total DNA was extracted from thoraces using phenol-chloroform extraction and ethanol precipitation (Sambrook et al., 1989).

\section{PCR amplification and endonuclease digestion}

Mitochondrial DNA was amplified in a Biometra thermocycler. The PCR reaction was performed with the corresponding $1 \times$ buffer, $2 \mathrm{mM} \mathrm{MgCl}_{2}, 0.2 \mathrm{~mm}$ of each dNTP, $0.15 \mu \mathrm{M}$ of primers E2 and H2 (Garnery et al., 1992) and 1 unit of polymerase in a total volume of $30 \mu \mathrm{L}$. Reactions were submitted to an initial denaturation of $5 \mathrm{~min}$ at $96^{\circ} \mathrm{C}, 30$ cycles of $95^{\circ} \mathrm{C}$ for $0.5 \mathrm{~min}, 50^{\circ} \mathrm{C}$ for $1.5 \mathrm{~min}$ and $72^{\circ} \mathrm{C}$ for $1.5 \mathrm{~min}$, and a final extension of $10 \mathrm{~min}$ at $72^{\circ} \mathrm{C}$. Five $\mu \mathrm{L}$ were electrophoresed in a $1.5 \%$ agarose gel and $20 \mu \mathrm{L}$ aliquots of the PCR product were digested with the restriction enzyme $\mathrm{DraI}$ at $37^{\circ} \mathrm{C}$ for $4-12 \mathrm{~h}$. Restriction fragments were separated on $8 \%$ acrylamide gels and stained with ethidium bromide.

\section{DNA purification and sequencing}

The amplified DNA fragments were extracted from the agarose gels and purified using the DNA Purification 
Table 1 Collection data for Apis cerana. The number of colonies $(N)$ sampled and the mtDNA haplotype are given for each sampling locality

\begin{tabular}{|c|c|c|}
\hline Locality & $N$ & Haplotype \\
\hline \multicolumn{3}{|l|}{ Mindanao (Min) } \\
\hline Palomolok & 2 & $\mathrm{Cel}$ \\
\hline Tacurong & 1 & Ce1 \\
\hline Santos City & 1 & $\mathrm{Ce} 1$ \\
\hline Bunawan & 2 & $\mathrm{Ce} 1$ \\
\hline Ozamys City & 1 & $\mathrm{Ce} 1$ \\
\hline Panabo & 1 & Ce1 \\
\hline Digos & 2 & Ce1 \\
\hline Malita & 1 & $\mathrm{Ce} 1$ \\
\hline Kidapawan & 2 & $\mathrm{Ce} 1$ \\
\hline \multicolumn{3}{|l|}{ Visayan Islands (Vis) } \\
\hline S. Joaquin (Panay) & 2 & Cel \\
\hline Valencia (Negros Oriental) & 1 & $\mathrm{Ce} 1$ \\
\hline Negros Occidental & 2 & $\mathrm{Ce} 1$ \\
\hline Argao (Cebu) & 1 & Cel \\
\hline Isabel (Leyte) & 1 & $\mathrm{Ce} 1$ \\
\hline \multicolumn{3}{|l|}{ Palawan (Pal) } \\
\hline Roxas & 2 & $\mathrm{Ce} 3$ \\
\hline El Nido & 1 & $\mathrm{Ce} 3$ \\
\hline Taytay & 1 & $\mathrm{Ce} 3$ \\
\hline Brooke's Point & 1 & $\mathrm{Ce} 4$ \\
\hline Aborlan & 1 & $\mathrm{Ce} 4$ \\
\hline Puerto Princesa & 2 & $\mathrm{Ce} 4$ \\
\hline Quezón & 3 & $\mathrm{Ce} 3$ \\
\hline \multicolumn{3}{|l|}{ Luzon (Luz) } \\
\hline \multicolumn{3}{|l|}{ Highlands } \\
\hline Campo Sioco & 3 & $\mathrm{Ce} 2$ \\
\hline Baguio City & 2 & $\mathrm{Ce} 2$ \\
\hline Tublay & 3 & $\mathrm{Ce} 2$ \\
\hline \multicolumn{3}{|l|}{ Lowlands } \\
\hline S. Vicente & 1 & $\mathrm{Ce} 2$ \\
\hline Rizal & 1 & $\mathrm{Ce} 2$ \\
\hline S. José City & 1 & $\mathrm{Ce} 2$ \\
\hline Batac & 2 & $\mathrm{Ce} 2$ \\
\hline Los Baños & 1 & $\mathrm{Ce} 2$ \\
\hline Bay & 1 & $\mathrm{Ce} 2$ \\
\hline Nagcarlan & 1 & $\mathrm{Ce} 2$ \\
\hline
\end{tabular}

Kit 'Easy Pure' from Biozym. The fragments were directly sequenced with the same primers used in the PCR reactions. Both strands of the intergenic region including the noncoding region and the $5^{\prime}$ end of the COII gene were sequenced.

\section{Sequence analysis}

DNA sequences were aligned using the multiplesequence alignment program CLUSTAL $\mathrm{w}$ (Thompson et al., 1994). MEGA program version 1.01 (Kumar et al., 1993) was used for estimating evolutionary distances
(Tamura \& Nei, 1993) and phylogenetic analyses were performed using the PHYLIP 3.5c package (Felsenstein, 1993). Analyses were performed on 1000 bootstrapped data sets generated by the program SEQBOOT. DNADIST with the Kimura two-parameter distance option (Kimura, 1980) was used to estimate divergences between sequences with a transition/transversion ratio of 2.0. Trees were constructed using UPGMA (NEIGHBOR) and a consensus tree was built from the resulting 1000 trees using the program CONSENSE.

\section{Results}

\section{Restriction analysis}

In the 47 colonies sampled, we detected no length polymorphism in the PCR-amplified fragment. The size of this product was about $500 \mathrm{bp}$ (data not shown) including the tRNAleu, the intergenic region of $\approx 89 \mathrm{bp}$ and the $5^{\prime}$ end of the cytochrome oxidase gene II.

After the analysis with the enzyme DraI, four different restriction patterns were obtained, corresponding to the haplotypes named $\mathrm{Ce} 1, \mathrm{Ce} 2, \mathrm{Ce} 3$ and $\mathrm{Ce} 4$ (Fig. 2a). Haplotypes $\mathrm{Ce} 1, \mathrm{Ce} 2$ and $\mathrm{Ce} 3$ showed four fragments whereas $\mathrm{Ce} 4$ showed only three because of the lack of one restriction site in its intergenic region. Haplotypes $\mathrm{Ce} 1$ and $\mathrm{Ce} 3$ showed a very similar restriction pattern but the different mobility of the restriction fragments suggested that the base composition of these two haplotypes may be different, as was revealed with the sequence analysis (see below). The putative restriction maps based on the partial sequence and the restriction patterns are shown in Fig. 2(b). All the haplotypes share the presence of the restriction sites numbered 2 and 3; in the haplotypes $\mathrm{Ce} 1$ and $\mathrm{Ce} 3$ there is another restriction site located in the intergenic region, and a third restriction site is supposed to be located along the COII sequence of the haplotype $\mathrm{Ce} 2$.

No variation in mtDNA patterns was found within the islands except in Palawan where two haplotypes coexist. The haplotype Cel was present in the colonies from both Mindanao and Visayan Islands (Table 1). $\mathrm{Ce} 2$ was present in Luzon and haplotypes $\mathrm{Ce} 3$ and $\mathrm{Ce} 4$ were typical for the island of Palawan. The colonies from Luzon were sampled from the highland and the lowland regions of this island and we were unable to detect variation in the mtDNA of these colonies.

\section{Sequence analysis}

Approximately $310 \mathrm{bp}$ of the $500 \mathrm{bp}$ PCR-amplified fragment were successfully sequenced in both directions. Figure 3 shows the partial sequence of the haplotypes found in this study, encompassing the intergenic 
(a)

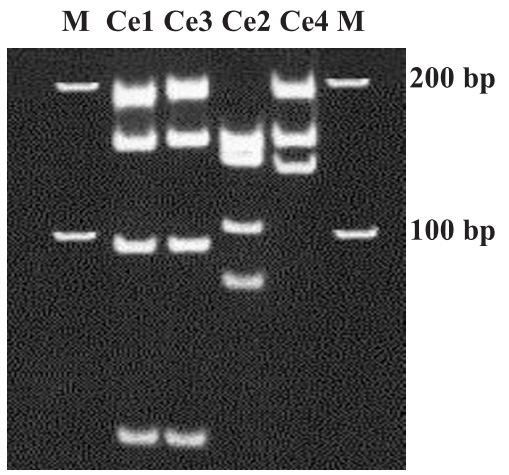

(b)

Fig. 2 (a) Fragments of Apis cerana mtDNA in an $8 \%$ acrylamide gel after digestion with the enzyme DraI. Lane 1 is the haplotype $\mathrm{Ce} 1$, lane 2 is $\mathrm{Ce} 3$, lane 3 is Ce 2 and lane 4 is Ce4. The different mobility of the restriction fragments in lanes 1 and 2 suggests different base pair composition of the mtDNA region between the samples from MindanaoVisayan Islands and Palawan. $\mathbf{M}$ is the molecular weight marker (100 bp ladder, Gibco BRL). (b) Putative restriction maps of the intergenic PCR-amplified region partially confirmed with the sequence. Restriction sites are numbered from 1 to 4 and the bar corresponds to $100 \mathrm{bp}$.
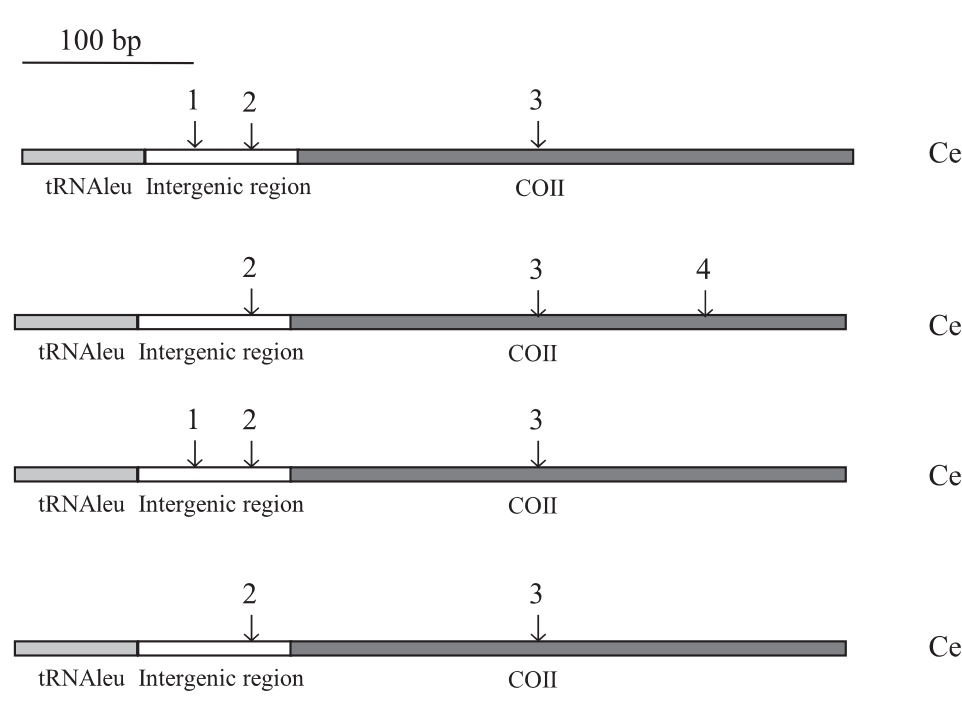

Ce1 noncoding region and the $5^{\prime}$ end of the COII gene. Restriction sites of the DraI enzyme are underlined and indicated with bold letters. The size of the intergenic region in the mitochondrial haplotypes described here ranged between 92 and $96 \mathrm{bp}$ and the G-C content varied from $3.2 \%$ to $9.2 \%$.

When our data were combined with those haplotypes forming the 'Philippine group' described in Smith \& Hagen (1997) some similarities and differences were found (Fig. 4): the intergenic regions showed the same motifs at the 5'and $3^{\prime}$ ends that correspond to stem sequences (Cornuet et al., 1991); the haplotype Ce1 (found in our samples from Mindanao and the Visayan Islands) is related to the haplotype found in the previous study in Mindanao but some bases were different (four transversions and four deletions); the haplotype $\mathrm{Ce} 2$ (from the lowland and highland altitude areas in Luzon) had the same sequence as Luzon1 except for one deletion; and the two haplotypes described for the samples from Palawan, $\mathrm{Ce} 3$ and $\mathrm{Ce} 4$, were more variable in the sequences than those in Smith \& Hagen
(1997). A total of 31 nucleotide sites were variable among the nine mtDNA haplotypes.

The fragment of the COII gene sequenced in these samples was $216 \mathrm{bp}$ long. Twelve nucleotides were variable $(5.5 \%)$; this nucleotide variation consisted of three transversions $(\mathrm{A} \leftrightarrow \mathrm{T})$ and nine transitions (8 $\mathrm{T} \leftrightarrow \mathrm{C}$ and $1 \mathrm{~A} \leftrightarrow \mathrm{G}$ ). Eight of the mutations were nonsilent.

\section{Phylogenetic analysis}

Over the 312 bp analysed, 30 were variable and five were phylogenetically informative. Figure 5(a) shows the consensus tree based on 1000 trees constructed under the UPGMA method using the $312 \mathrm{bp}$ sequenced from the mitochondrial region (including coding and noncoding sequences). The high bootstrap scores give confidence to support the separation of the populations from Palawan in a well separated branch. These populations appear to be more related to the populations from Luzon than to the populations from Mindanao and the Visayan 


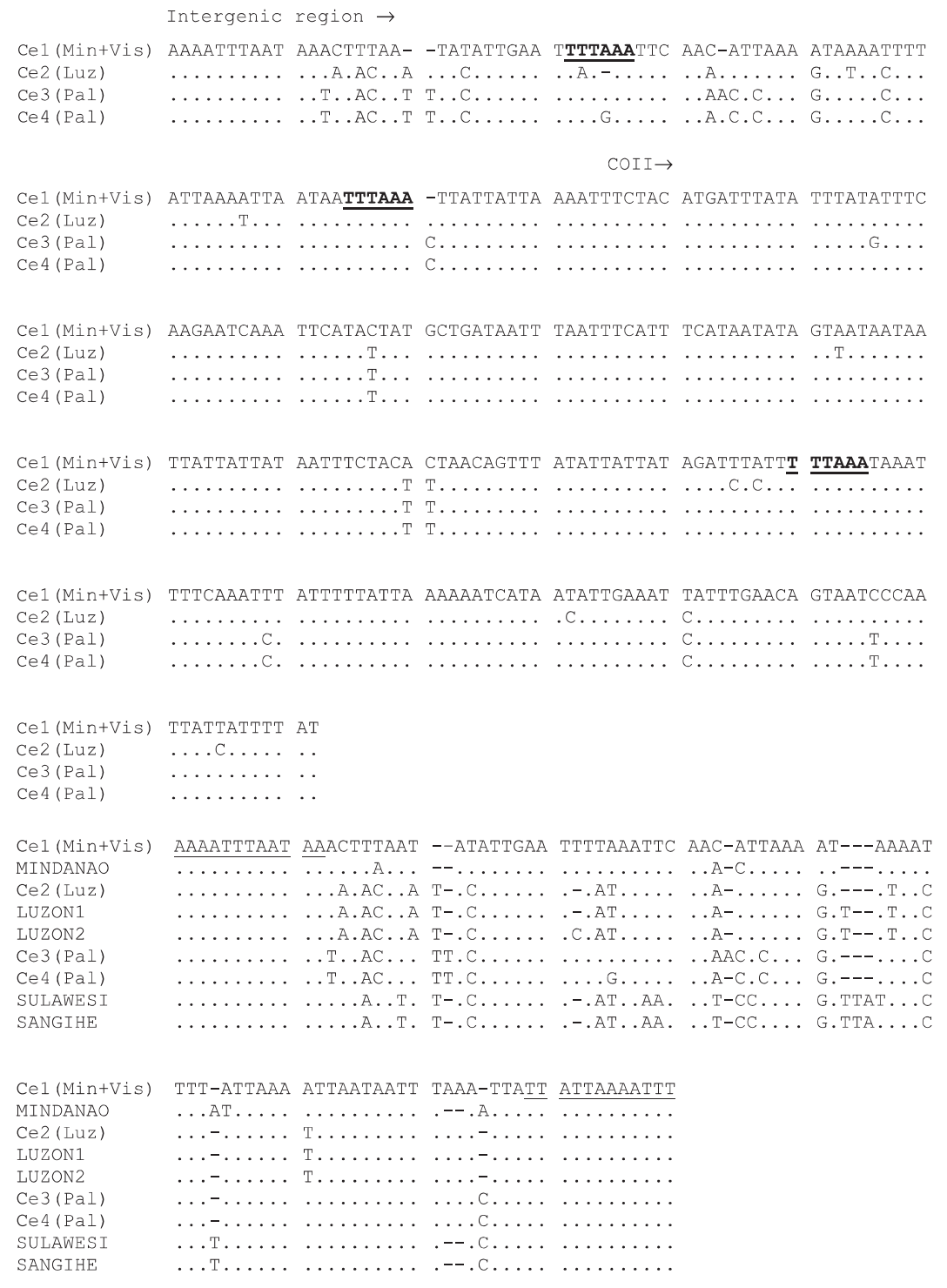

Fig. 3 Nucleotide sequence of the intergenic noncoding region and the $5^{\prime}$ end of the COII gene of the four haplotypes in Apis cerana populations from the Philippines. Dots correspond to identical nucleotides and dashes indicate gaps. The restriction sites of the enzyme DraI are underlined and pointed out with bold letters. For abbreviated names see Table 1.

Fig. 4 Sequence of the noncoding intergenic region in Apis cerana haplotypes from the Philippines compared to the sequences from related localities (in capital letters) reported by Smith \& Hagen (1997). The underlined bases correspond to stem sequences. See Table 1 for abbreviated names.
Islands. The distances between populations with different haplotypes ranged between $6.77 \%$ (Luzon and Mindanao + Visayan Islands) and $0.67 \%$ (between those populations from Palawan that have different mitochondrial haplotypes) (Fig. 5b).

\section{Discussion}

\section{Haplotype variability}

Our results confirm the usefulness of combining the DraI test with the nucleotide composition of the tRNAleu-COII region in the analysis of the biogeography of island populations isolated for different periods of time. These molecular approaches have contributed to a better understanding of the A. mellifer a subspecies complex as shown for the Canary Islands by De la Rúa et al. (1998) and in the present study for the Philippines populations of A. cerana. With this DraI test, we have been able to differentiate four different haplotypes within the islands studied in the Philippines.

Using 39 morphometric characters, three groups of honeybee populations from the Philippine Islands could be distinguished: (i) the Philippines general group; (ii) the Luzon highland group; and (iii) the Palawan group (Tilde et al. unpubl. obs.). The results obtained in our molecular study partially confirm the previous grouping. There is only one discrepancy, the Palawan group is homogeneous at the morphological level whereas two different groups have been found using the mitochondrial approach.

Populations from Mindanao and the Visayan Islands share the same haplotype, Cel, a fact that could be explained by gene flow between these islands because of 
(a)

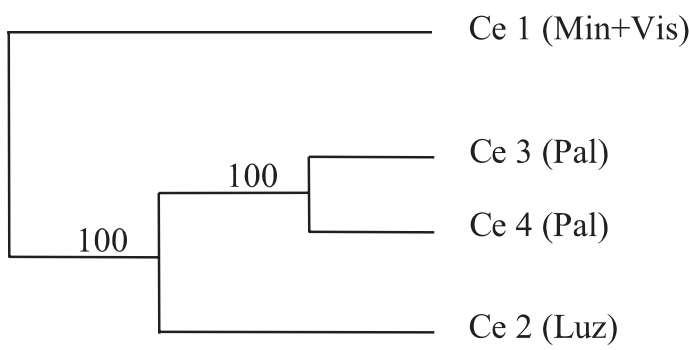

(b)

Fig. 5 (a) Unrooted phylogenetic tree of Apis cerana haplotypes produced by the UPGMA method. The distances used have been calculated using Kimura's twoparameter correction method. (b) Distances (upper right matrix) and standard errors (lower left matrix) between groups of populations with the same haplotype.

\begin{tabular}{lllll}
\hline & Ce1 (Min+Vis) & Ce2 (Luz) & Ce3 (Pal) & Ce4 (Pal) \\
\hline Ce1 (Min+Vis) & & 0.0677 & 0.0571 & 0.0571 \\
Ce2 (Luz) & 0.0159 & & 0.0551 & 0.0516 \\
Ce3 (Pal) & 0.0150 & 0.0134 & & 0.0067 \\
Ce4 (Pal) & 0.0150 & 0.0129 & 0.0050 & \\
\hline
\end{tabular}

their geographical proximity. The honeybee populations from Luzon are homogeneous in their mitochondrial genome, even though the colonies were sampled from very different regions of the island. Luzon was isolated from the other islands in the late Pleistocene (Smith, 1991), so these populations had the chance to diverge and homogenize their mtDNA sequence giving rise to the unique haplotype Ce2. Populations from Palawan show two haplotypes with different frequencies, one of which, $\mathrm{Ce} 3$, has the same restriction pattern as $\mathrm{Ce} 1$, but a different mobility in the acrylamide gel, caused by a different base composition. The molecular data show the presence of mitochondrial polymorphism in the population from this island, or two groups of populations instead of one as considered morphologically.

Our data show that the DraI test developed in A. mellifera subspecies can be successfully used in other Apis species, taking advantage of the high variability in the A-T rich intergenic region. The current results on mtDNA variability at the population level in A. cerana indica from the Philippines, make it a promising tool in further studies of the phylogeographical distribution of A. cerana subspecies and populations.

\section{Sequence analysis and genetic relationships}

The mtDNA region sequenced showed both a high $\mathrm{A}+\mathrm{T}$ content (mean of $88.45 \%$ ), as has been previously reported for the whole mtDNA of $A$. mellifera
(Crozier \& Crozier, 1993), and more transitional events, as occurs in other organisms (DeSalle, 1992).

These A. cerana populations have shown a high level of genetic variability, which agrees with the great variation previously found in other studies of the geographical (Ruttner, 1988, 1992; Peng et al., 1989), morphometric (Damus \& Otis, 1997) and molecular (Deowanish et al., 1996; Smith \& Hagen, 1997) variation in A. cerana populations. In fact, three of the four haplotypes described here for the first time are different in sequence from those previously described, suggesting that in Mindanao, the Visayan Islands and Palawan there is a remarkable amount of intra-island variation in the mitochondrial genome. This could be because of the size and environmental heterogeneity of these islands, which offer a possible scenario for haplotype diversification.

The Philippines populations cluster in agreement with the geological history of these islands. One branch includes the populations from Mindanao and the Visayan Islands, islands that are more geographically distant from the others and that could have been separated from the mainland for a long time. The other branch includes Luzon and Palawan, the populations from Palawan showing a well supported branch that indicates their mitochondrial differentiation from the other populations.

Smith \& Hagen (1997) reported that Mindanao, the Visayan Islands and Luzon have probably never been connected to the mainland, and that mitochondrial genomes are highly divergent on long-isolated islands.

(C) The Genetical Society of Great Britain, Heredity, 84, 124-130. 
Our results confirm this. The genetic distance between the populations from Luzon and Mindanao and the Visayan Islands is much higher than between the populations on Palawan. This island was joined to the mainland during the Pleistocene and populations located here have similar mitochondrial genomes with a very low genetic distance between them. These populations are expected to be most closely related to those from the mainland, but more data are needed to verify this hypothesis. The presence of two haplotypes in Palawan suggests that different mutational events have occurred in this island giving rise to polymorphisms in the mtDNA of these bees.

\section{Acknowledgements}

We are grateful to Dr J. Galián and Prof. Dr J. Serrano for their suggestions and help that improved the paper, and to F. Sánchez-Gea for helping with the figures. This work has been undertaken with European Commission (DG 12) and Deutsche Forschungsgemeinschaft financial support. This manuscript has been improved by the comments of two anonymous reviewers.

\section{References}

CORNUET, J. M. AND GARNERY, L. 1991. Mitochondrial DNA variability in honeybees and its phylogeographic implications. Apidologie, 22, 627-642.

CORnuet, J. M., GARnery, L. AND SOlignaC, M. 1991. Putative origin of the intergenic region between COI and COII of Apis mellifera L. mitochondrial DNA. Genetics, 128, 393-403.

CROZIER, R. H. AND CROZIER, C. 1993. The mitochondrial genome of the honeybee Apis mellifera: complete sequence and genome organisation. Genetics, 133, 97-117.

DAMUS, M. S. AND OTIS, G. W. 1997. A morphometric analysis of Apis cerana $\mathrm{F}$. and Apis nigrocincta Smith populations from Southeast Asia. Apidologie, 28, 309-323.

DE LA RÚA, P., SERRANO, J. AND GALIÁN, J. 1998. Mitochondrial DNA variability in the Canary Islands honeybees (Apis mellifera). Mol. Ecol., 7, 1543-1547.

DEOWANISH, S., NAKAMURA, J., MATSUKA, M. AND KIMURA, K. 1996. MtDNA variation among subspecies of Apis cerana using restriction fragment length polymorphism. Apidologie, 27, 407-413.

DESALLE, R. 1992. The phylogenetic relationships of flies in the family Drosophilidae deduced from mtDNA sequences. Mol. Phylogenet. Evol., 1, 34-40.

FELSENSTEIN, J. 1993. PHYLIP (Phylogeny inference package), version 3.5c. Distributed by the author. Department of Genetics, University of Washington, Seattle.

GARNERY, L., VAUTRIN, D., CORNUET, J. M. AND SOLIGNAC, M. 1991. Phylogenetic relationships in the genus Apis inferred from mitochondrial DNA sequence data. Apidologie, 22, 87-92.
GARNERY, L., CORNUET, J. M. AND SOLIGNAC, M. 1992. Evolutionary history of the honey bee Apis mellifera inferred from mitochondrial DNA analysis. Mol. Ecol., 1, 145-154.

GARNERY, L., SOLIGNAC, M., CELEBRANO, G. AND CORNUET, J. M. 1993. A simple test using restricted PCR-amplified mitochondrial DNA to study the genetic structure of Apis mellifera L. Experientia, 49, 1016-1021.

GARNERY, L., MOSSHINE, E. H., OLDROYD, B. P. AND CORNUET, J. M. 1995. Mitochondrial DNA variation in Moroccan and Spanish honey bee populations. Mol. Ecol., 4, 465-471.

KUMAR, S., TAMORA, K. AND NEI, M. 1993. MEGA: Molecular Eolutionary Genetic Analysis, 1.0 edn. Pennsylvania State University, University Park, PA.

KIMURA, M. 1980. A simple model for estimating evolutionary rates of base substitutions. J. Mol. Evol., 16, 111-120.

MORITZ, R. F. A., CORNUET, J. M., KRYGER, P., GARNERY, L. AND HEPBURN, H. R. 1994. Mitochondrial DNA variability in South African honeybees (Apis mellifera L.). Apidologie, 25, 169-178.

MORITZ, R. F. A., BEYE, M. AND HEPBURN, H. R. 1998. Estimating the contribution of laying workers to population fitness in African honeybees (Apis mellifera) with molecular markers. Insectes Sociaux, 45, 277-287.

PENG, Y. S., NASR, M. E. AND LOCKE, S. J. 1989. Geographical races of Apis cerana Fabricius in China and its distribution. Review of recent Chinese publications and a preliminary statistical analysis. Apidologie, 20, 9-20.

RUTTNER, F. 1988. Biogeography and Taxonomy of Honeybees. Springer, Berlin.

RUTTNER, F. 1992. Naturgeschichte der Honigbienen. Ehrenwirth, München.

SAMBROOK, J., FRITSCH, E. AND MANIATIS, T. 1989. Molecular Cloning. A Laboratory Manual. Cold Spring Harbor Laboratory Press, Cold Spring Harbor, NY.

SIMON, C., FRATI, F., BECKENBACH, A., CRESPI, B., LIU, H. AND FLOOK, P. 1994. Evolution, weighting and phylogenetic utility of mitochondrial gene sequences and a compilation of conserved polymerase chain reaction primers. Ann. Entomol. Soc. Am., 87, 651-701.

SMITH, D. R. 1991. Diversity in the Genus Apis. Westview Press, Boulder, CO.

SMITH, D. R. AND HAGEN, R. H. 1997. The biogeography of Apis cerana as revealed by mitochondrial DNA sequence data. J. Kansas Entomol. Soc., 69, 294-310.

TAMURA, K. AND NEI, M. 1993. Estimation of the number of nucleotide substitutions in the control region of mitochondrial DNA in humans and chimpanzees. Mol. Biol. Evol., 10, $512-526$.

THOMPSON, J. D., HIGGINS, D. G. AND GIBSON, T. J. 1994. CLUSTAL $\mathrm{W}$ : improving the sensitivity of progressive multiple sequence alignment through sequence weighting, position specific gap penalties and weight matrix choice. Nucl. Acids Res., 22, 4673-4680.

WILLIS, L. G., WINSTON, M. L. AND HONDA, B. M. 1992. Phylogenetic relationships in the honeybee (genus Apis) as determined by the sequence of the cytochrome oxidase II region of mitochondrial DNA. Mol. Phylogenet. Evol., 1, 169-178. 